By using several locations a better average analysis can be obtained. The spots caused by the operation of the arc can readily be removed after the analysis.

Résumé-Les auteurs décrivent une méthode spectroanalytique pour l'étude non destructive des bronzes archéologiques. Des échantillons de toutes dimensions et de toutes formes peuvent être analysées quantitativement, tant qu'il y a une surface plane de $2 \mathrm{~mm}$ de diamètre. Un petit travail est nécessaire pour préparer les échantillons. Il est possible d'utiliser différentes positions pour l'analyse afin d'obtenir une meilleure moyenne. Les spotes dus à l'impact de l'arc peuvent facilement être éliminés quand l'analyse a été effectuée.

\title{
LITERATUR
}

1 K. Doerffel, Z. analyt. Chem., 1962, 185, 1.

2 M. van Doorselaer, Mikrochim Acta, 1951, 36/37, 513.

3 J. Gillis, M. van Doorselaer und J. Ramirez-Munos, Anal. Real. Soc. Espan. Fis. Quím., Ser. B., $1951,47,609$.

- R. Geyer, K. Doerffel und H. Kirst, Z. analyt. Chem., 1960, 172, 326.

5 H. Otto, Spectrochim Acta, 1940, 1, 381.

- A. N. Saidel, W. K. Prokoffiew und S. M. Raiski, Spektraltabellen. (U'bersetzung aus den Russischen), VEB Verlag Technik, Berlin, 1955.

$7 \mathrm{H}$. Scheller, Einführung in die angewandte spektrochemische Analyse. VEB Verlag Technik, Berlin, 1961.

8 W. Seith, Metall u. Erz, 1944, 41, 35.

'I. R. Sselimchanow, Ber. Akad. Wiss. Aserbeidschan, 1957, 13, 967.

10 C. Zeiss, Arbeitsvorschriften für die quantitative spektrochemische Bestimmung von Metallen.

11 K. Zimmer, Z. L. Szabó und P. Patay, Magyar Kem. Folyóirat, 1962, 68, 515.

\section{Determination of small amounts of zirconium-I: Gravimetric procedures using mandelic acid and its derivatives}

\author{
(Received 23 October 1962. Accepted 29 January 1963)
}

THE use of mandelic acid and related glycolic acid derivatives ${ }^{1}$ to precipitate zirconium ${ }^{\mathrm{IV}}$ has been reviewed by Hahn. ${ }^{2}$ The selectivity of this group of reagents for zirconium has ensured their use; the reagent most favoured for general use has been $p$-bromomandelic acid.

In connection with the gravimetric determination of small amounts of zirconium in refractory samples, such as alloys, glasses and minerals, ${ }^{8}$ the optimum and limiting conditions have been investigated for mandelic acid, $p$-bromomandelic acid and a heretofore only briefly studied reagent, $m$-nitromandelic acid.

\section{EXPERIMENTAL}

After washing with acetone and ethanol, dissolve 1-g quantities of pure zirconium metal in concentrated acid, with heating, and dilute to 1 litre:

Solution A: Dissolve in $25 \mathrm{ml}$ of $\mathrm{HNO}_{3}+1 \mathrm{ml}$ of HF, then evaporate with 30-35 $\mathrm{ml}$ of $\mathrm{H}_{2} \mathrm{SO}_{4}$. Solution B: Dissolve in $25 \mathrm{ml}$ of $\mathrm{HNO}_{3}+25 \mathrm{ml}$ of $\mathrm{H}_{2} \mathrm{SO}_{4}$, then evaporate with $25 \mathrm{ml}$ of $\mathrm{H}_{8} \mathrm{SO}_{4}$.

Solution C: Dissolve in $50 \mathrm{ml}$ of $\mathrm{H}_{\mathbf{g}} \mathrm{SO}_{4}$.

Solution D: Dissolve in $25 \mathrm{ml}$ of $\mathrm{HCl}+25 \mathrm{ml}$ of $\mathrm{H}_{2} \mathrm{SO}_{4}$.

These solutions were dispensed with calibrated pipettes (accurate to $1 \%$ or better).

Precipitation was generally made by adding the reagent solution dropwise from a burette with constant stirring of the test solution. Filtration was made through No. 40 Whatman filter paper. Weighings of the ignited crucible, empty/or containing ignited precipitate and filter paper ash, were reproducible to $\pm 0.01 \mathrm{mg}$. The filter ash was $0.02-0.03 \mathrm{mg}$.

Recommended procedures are given following discussion of the data; procedures used in studying the reagents follow. 
TABLE I.-FACTORS IN PRECIPITATION OF ZIRCONIUM WITH MANDELIC ACID:

(A) Effect of original zirconium solution composition ${ }^{a}$

\begin{tabular}{cccc}
\hline \multirow{2}{*}{$\begin{array}{c}\text { Stock } \\
\text { solution }\end{array}$} & \multicolumn{3}{c}{ Zirconium found for amount taken, $\mathrm{mg}$} \\
\cline { 2 - 4 } & 1.00 & 3.00 & 10.00 \\
\hline A & 1.04 & 2.96 & 9.81 \\
B & 0.98 & 3.03 & 9.98 \\
C & 1.00 & 2.96 & 8.88 \\
D & 0.99 & 3.00 & 10.06 \\
\hline
\end{tabular}

Total volume: $50 \mathrm{ml}$. Concentrations: $\mathrm{Zr} \mathrm{0.22,0.66}$ and 2.19 $\mathrm{mM}$; MA 0.33M; acid 2.0-2.2M.

(B) Zirconium concentration (10\% MA precipitant) ${ }^{\mathrm{C}}$

\begin{tabular}{|c|c|c|}
\hline \multicolumn{3}{|c|}{ Zirconium } \\
\hline $\begin{array}{c}\text { Taken, } \\
m g\end{array}$ & $\begin{array}{c}\text { Found, } \\
m g\end{array}$ & $\begin{array}{c}\text { Deviation, } \\
\% \\
\end{array}$ \\
\hline $0 \cdot 10^{2}$ & $\begin{array}{l}0.05_{9}, 0.06_{0} \\
0.06_{7}, 0.07_{0} \\
0.08_{9}, 0 \cdot 10_{3}\end{array}$ & +3 to -41 \\
\hline $0 \cdot 30^{\mathrm{b}}$ & $0.28_{5}, 0.29_{0}$ & $-8,-3$ \\
\hline $0.50^{\mathrm{a}}$ & $0.48_{6}, 0.50_{2}$ & $-3, \pm 0$ \\
\hline $0.70^{\mathrm{b}}$ & $0 \cdot 70_{0}$ & \pm 0 \\
\hline $1.00^{\mathrm{b}}$ & $0.99,1.03$ & $-1,+3$ \\
\hline
\end{tabular}

a Zirconium stock solution $\mathrm{C}$.

b Zirconium stock solution D.

c Total volume: $20 \mathrm{ml}$. Concentrations: $\mathrm{Zr} 0.055$ to $0.548 \mathrm{mM}$; acid $1.9 \mathrm{M}$; MA $0.33 \mathrm{M}$.

(C) Added hydrochloric acid (10\% MA as precipitant) ${ }^{\mathrm{b}}$

\begin{tabular}{cccc}
\hline $\mathrm{HCl}^{\mathrm{a}}{ }^{\mathrm{a}}$ & \multicolumn{3}{c}{ Zirconium } \\
\cline { 2 - 4 } & $\begin{array}{c}\text { Taken, } \\
m g\end{array}$ & $\begin{array}{c}\text { Found, } \\
m g\end{array}$ & $\begin{array}{c}\text { Deviation, } \\
\%\end{array}$ \\
\hline 1.9 & 1.00 & 0.98 & -2 \\
2.6 & 1.00 & 1.03 & +3 \\
3.2 & 1.00 & 1.00 & \pm 0 \\
3.8 & 1.00 & 0.99 & -1 \\
\hline
\end{tabular}

a Concentration in the test solution.

b Total volume: $20 \mathrm{ml}$. Concentrations:

Zr 0.548 mM; MA 0.33M.

(D) Mandelic acid concentration and digestion time ${ }^{\mathrm{a}}$

\begin{tabular}{ccccc}
\hline $\begin{array}{c}\text { Mandelic } \\
\text { acid } \\
\text { reagent } \\
\%\end{array}$ & $\begin{array}{c}\text { Digestion } \\
\text { time, } \\
\text { min }\end{array}$ & $\begin{array}{c}\text { Taken, } \\
m g\end{array}$ & $\begin{array}{c}\text { Found, } \\
m g\end{array}$ & $\begin{array}{c}\text { Zeviation, } \\
\%\end{array}$ \\
\hline 2 & 20 & $1 \cdot 0$ & No ppt. & -100 \\
3 & 20 & 1.0 & No ppt. & -100 \\
4 & 20 & $1 \cdot 0$ & 0.45 & -55 \\
4 & 40 & $1 \cdot 0$ & $0 \cdot 51$ & -49 \\
4 & 60 & $1 \cdot 0$ & 0.59 & -41 \\
6 & 20 & 1.0 & 0.74 & -26 \\
6 & 40 & 1.0 & 0.84 & -16 \\
6 & 60 & 1.0 & 0.85 & -15 \\
\hline
\end{tabular}

a Total volume: $50 \mathrm{ml}$. Concentrations: $\mathrm{Zr} 0.219 \mathrm{mM}$; acid $2 M$; MA $0.066,0 \cdot 10,0.13$ and $0.20 M$. 
Mandelic acid. Dissolve $10 \mathrm{~g}$ of mandelic acid (MA) in warm water and dilute to $100 \mathrm{ml}$. (1) Transfer zirconium solution and $8 \mathrm{ml}$ of $\mathrm{HCl}$ to a $150-\mathrm{ml}$ beaker, dilute to $25 \mathrm{ml}$, heat to $50-60^{\circ}$, add $25 \mathrm{ml}$ of MA solution and digest for $20 \mathrm{~min}$ at $80-85^{\circ}$. Filter precipitate, wash with $25-30 \mathrm{ml}$ of warm solution ( $2 \mathrm{ml}$ of $\mathrm{HCl}+5 \mathrm{~g}$ of MA per $100 \mathrm{ml}$ ), slowly char paper and precipitate in a porcelain crucible, ignite, cool and weigh as $\mathrm{ZrO}_{2}$.

(2) Transfer zirconium solution and $3 \mathrm{ml}$ of $\mathrm{HCl}$ to a $50-\mathrm{ml}$ beaker, dilute to $10 \mathrm{ml}$, heat to $50-60^{\circ}$, add $10 \mathrm{ml}$ of MA solution and digest for $20 \mathrm{~min}$ at $80-85^{\circ}$. Filter precipitate, wash with $10 \mathrm{ml}$ of warm solution as before, but ignite in a platinum crucible.

p-Bromomandelic acid. Dissolve $1.5 \mathrm{~g}$ of $p$-bromomandelic acid (BMA) in warm water, filter and dilute to $100 \mathrm{ml}$.

Transfer zirconium solution and $3 \mathrm{ml}$ of $\mathrm{HCl}$ to a $50-\mathrm{ml}$ beaker, dilute to $10 \mathrm{ml}$, heat to $50-60^{\circ}$, add $10 \mathrm{ml}$ of BMA solution and digest for $15 \mathrm{~min}$ at $80-85^{\circ}$. Filter precipitate, wash with $10-25 \mathrm{ml}$ of hot water, char slowly in a platinum crucible and ignite at $900-1000^{\circ}$.

$\mathrm{m}$-Nitromandelic acid. Dissolve requisite amount of $m$-nitromandelic acid (NMA) in warm water, filter and dilute to $100 \mathrm{ml}$.

(1) Transfer zirconium solution to a $50-\mathrm{ml}$ beaker, dilute to $10 \mathrm{ml}$, heat to $45-60^{\circ}$, add $10 \mathrm{ml}$ of $5 \%$ or $4 \%$ NMA solution and digest for $10-15 \mathrm{~min}$ at $60-70^{\circ}$. Filter precipitate, wash with $10-15 \mathrm{ml}$ of warm $5 \%$ NMA and ignite in a platinum crucible.

(2) Transfer $1 \mathrm{ml}$ of zirconium solution $\mathrm{D}$ and $10 \mathrm{ml}$ of water to a $50-\mathrm{ml}$ beaker, heat to $50-60^{\circ}$, add 10 $\mathrm{ml}$ of $15 \%$ NMA solution and digest for $10-15 \mathrm{~min}$ at $60-70^{\circ}$. Filter precipitate, wash with $10 \mathrm{ml}$ of warm $5 \%$ NMA solution and ignite in a platinum crucible.

\section{Mandelic acid}

\section{RESULTS AND INTERPRETATION}

Zirconium was determined at the 1 to $10-\mathrm{mg}$ level by procedure (1) [Table I(A)] and at the 0.1 to 1-mg level by procedure (2) [Table I(B)]. Procedure (2) was also applied at varying concentrations of hydrochloric acid and mandelic acid (MA), and for varying digestion times [Tables $I(C)$ and $I(D)$ ]. The following conclusions can be drawn:

(1) Zirconium level: $10 \% \mathrm{MA}$ is satisfactory for the determination of small amounts $(\geqslant 0.5 \mathrm{mg})$; results are low for $<0.3 \mathrm{mg}$.

(2) Precipitant concentration: 10\% MA is adequate for quantitative precipitation at the $0.3-\mathrm{mg}$ zirconium level and above; it is difficult to obtain quantitative results at the 1-mg level with lower MA concentrations.

(3) Acid concentration: No difference was found in the range of 3-6M hydrochloric acid (sometimes augmented by free sulphuric acid from the zirconium solution).

(4) Digestion and washing: To obtain a good precipitate, heating for $20 \mathrm{~min}$ at $80-85^{\circ}$ is necessary; longer periods give no improvement. Use of a wash solution containing $2 \mathrm{ml}$ of concentrated hydrochloric acid and $5 \mathrm{~g}$ of MA per $100 \mathrm{ml}$ are necessary because of the appreciable solubility of zirconium tetramandelate in water.

\section{p-Bromomandelic acid}

The following conclusions can be drawn from the results of determining zirconium under various conditions (Table II):

(1) Zirconium level: $1.5 \%$ BMA is adequate for quantitative precipitation down to the $0 \cdot 1-\mathrm{mg}$ level. Excellent precision and accuracy are attainable at the 1-mg level.

(2) Precipitant concentration: $1.5 \%$ and $2 \%$ BMA are equally good for precipitating zirconium from 1-4M hydrochloric acid; less than 1.5\% BMA is unsatisfactory at the $0.1-\mathrm{mg}$ level.

(3) Digestion and washing: Because of the slow reaction between BMA and zirconium at room temperature, it is necessary to warm the solution. Temperatures near the boiling point of water apparently result in decomposition of BMA. A good crystalline precipitate is obtained by heating to $50-60^{\circ}$, adding BMA dropwise with constant stirring and digesting for about $15 \mathrm{~min}$ at $80-85^{\circ}$; longer times are unnecessary. Hot water is suitable for washing.

\section{m-Nitromandelic acid}

The following conclusions are evident from the use of $4 \%$ to $15 \%$ NMA as precipitant (Table III): (1) Zirconium level and acid concentration: In less acidic media zirconium quantitatively forms a brown precipitate. However, results are low at low NMA concentrations; $15 \%$ NMA is suitable for the determination of amounts of zirconium as low as $0.1 \mathrm{mg}$.

(2) Digestion period and temperature: It is helpful in obtaining a good precipitate to warm the solution and to add NMA dropwise, stirring constantly. For complete precipitation, it is necessary to digest the solution for $10-15 \mathrm{~min}$ at $60-70^{\circ}$. 
TABLE II.-FACTORS IN THE PRECIPITATION OF ZIRCONIUM WITH $p$-BROMOMANDELIC ACID ${ }^{\mathrm{a}}$

\begin{tabular}{|c|c|c|c|c|c|}
\hline \multirow{2}{*}{$\begin{array}{c}\text { Reagent } \\
\text { concn., } \\
\%\end{array}$} & \multirow[b]{2}{*}{$\begin{array}{c}\text { No. of } \\
\text { runs }\end{array}$} & \multicolumn{4}{|c|}{ Zirconium } \\
\hline & & $\begin{array}{l}\text { Taken, } \\
m g\end{array}$ & $\begin{array}{l}\text { Found, } \\
m g\end{array}$ & $\begin{array}{c}\text { Average, } \\
\quad m g\end{array}$ & $\begin{array}{c}\text { Standard } \\
\text { deviation, } \\
m g\end{array}$ \\
\hline $1 \cdot 0$ & 4 & $0 \cdot 10$ & $0.03-0.07$ & & \\
\hline $1 \cdot 5$ & 6 & $0 \cdot 10$ & $0 \cdot 090-0 \cdot 105$ & $0 \cdot 10$ & 0.006 \\
\hline 1.5 & 6 & 1.00 & $0.987-1.028$ & 1.002 & 0.015 \\
\hline $1 \cdot 5$ & 2 & $2 \cdot 00$ & $2.04,1.98$ & & \\
\hline 1.5 & 2 & 3.00 & $3.04,3.00$ & & \\
\hline 1.5 & 2 & $4 \cdot 00$ & $4.02,4.06$ & & \\
\hline 1.5 & 1 & 5.00 & 4.98 & & \\
\hline $2 \cdot 0$ & 4 & 1.00 & $0.992-1.021$ & 1.00 & 0.013 \\
\hline
\end{tabular}

a Total volume: $20 \mathrm{ml}$. Concentrations: $\mathrm{Zr} 0.055(0.1 \mathrm{mg}), 0.55(1 \mathrm{mg})$ to $2.75(5 \mathrm{mg}) \mathrm{mM}$; acid $1 \cdot 9-2 \cdot 1 M$.

TABLE III.-FACTORS IN THE PRECIPITATION OF ZIRCONIUM WITH $m$-NITROMANDELIC ACID ${ }^{d}$

\begin{tabular}{|c|c|c|c|c|}
\hline \multirow[b]{2}{*}{$\begin{array}{c}\mathrm{Zr} \\
\text { soln. }\end{array}$} & \multirow{2}{*}{$\begin{array}{c}\mathrm{HCl} \\
\text { added, } \\
m l\end{array}$} & \multirow{2}{*}{$\begin{array}{c}\text { Reagent } \\
\text { concn., } \\
\%\end{array}$} & \multicolumn{2}{|c|}{ Zirconium } \\
\hline & & & $\begin{array}{c}\text { Taken, } \\
m g\end{array}$ & $\begin{array}{c}\text { Found, } \\
m g\end{array}$ \\
\hline \multirow[t]{2}{*}{ A } & 0 & 5 & $2 \cdot 00$ & $0.99^{\mathrm{a}}$ \\
\hline & 1 & 5 & 2.00 & No ppt. \\
\hline B & 0 and 1 & 4 & $2 \cdot 00$ & No ppt. \\
\hline C & 0 and 1 & 5 & 2.00 & No ppt. \\
\hline D & 0 & 4 & 2.00 & 0.89 \\
\hline \multirow[t]{2}{*}{ D } & 0 & 5 & 2.00 & 1.07 \\
\hline & 1 and 2 & 5 & 2.00 & No ppt. \\
\hline \multirow[t]{2}{*}{ A } & 0 & 10 & 1.00 & $0.69^{1}$ \\
\hline & 1 & 10 & 1.00 & No ppt. \\
\hline \multirow[t]{2}{*}{ B } & 0 & 10 & 1.00 & $0.63^{\mathrm{P}}$ \\
\hline & 1 & 10 & 1.00 & No ppt. \\
\hline \multirow[t]{2}{*}{ C } & 0 & 10 & 1.00 & $0.50^{10}$ \\
\hline & 1 & 10 & 1.00 & No ppt. \\
\hline \multirow[t]{2}{*}{ D } & 0 & 10 & 1.00 & 0.89 \\
\hline & 1 & 10 & 1.00 & No ppt. \\
\hline \multirow[t]{3}{*}{ D } & 0 & $15^{\mathrm{e}}$ & $0 \cdot 100$ & $0.099^{0}$ \\
\hline & $0^{\mathrm{c}}$ & $15^{\mathrm{e}}$ & 1.00 & $0.98,1.00$ \\
\hline & 1 and 2 & $15^{\mathrm{e}}$ & 1.00 & No ppt. \\
\hline
\end{tabular}

a Precipitate washed with hot water; all other precipitates washed with warm $2 \% m$-nitromandelic acid, except as noted.

b Washed with $5 \% m$-nitromandelic acid.

- Without added $\mathrm{HCl}$; the $\mathrm{pH}$ is about 1.6; with added $\mathrm{HCl}$, it is between 0.0 and 0.2 .

d Total volume: $20 \mathrm{ml}$. $\mathrm{Zr}$ concentration: $0.55 \mathrm{mM}$ for $1 \mathrm{mg} ; 1 \cdot 10 \mathrm{mM}$ for $2 \mathrm{mg}$.

e Total acid concentration in these experiments: $<0.05 M$, ca. $0.05 M$, ca. $0.05 M,<0.7 M$. 
(3) Wash solution: Because of the appreciable solubility of the precipitate in water, a warm wash solution containing $5 \% \mathrm{NMA}$ is recommended.

\section{DISCUSSION}

To obtain satisfactory precipitation within a reasonable time, a large excess of reagent must be used; the weight ratios of reagent to zirconium (molar ratios in parentheses) are 250-10,000 (150$6,000)$ for MA, 30-1,500 (12-600) for BMA and 750-1,500 (350-700) for NMA.

Although MA is adequate for the gravimetric determination of zirconium at the $1-\mathrm{mg}$ level in a highly acidic medium, BMA is generally preferable because it avoids the use of a wash solution containing the reagent and gives better results at low zirconium levels. NMA is not satisfactory as a precipitant in highly acidic media; however, at $\mathrm{pH} 1.3$ or greater, it seems preferable to MA because of more rapid precipitation and better accuracy at low zirconium levels, e.g., $0.1 \mathrm{mg}$.; MA was not investigated at as low acidities as was NMA. NMA also gives more rapid precipitation than BMA. A wash solution containing reagent is necessary in the case of MA and NMA.

\section{Sensitivity}

Satisfactory results were obtained with BMA for solutions as dilute as $0.1 \mathrm{mg}$ of zirconium in a final volume of $20 \mathrm{ml} ; 0.05 \mathrm{mg}$ of zirconium (20-ml volume; $1.9 M$ hydrochloric acid; final BMA concentration $0.75 \%$; filtered after $3 \mathrm{hr}$ ) gave a residue corresponding to $0.04 \pm 0.01 \mathrm{mg}$.

\section{Interferences}

Anions which form complexes with zirconium, e.g., fluoride and sulphate, interfere in some zirconium methods; no such interference was indicated for the mandelate reagents by the use of the different zirconium solutions. Nevertheless, it is probably best to use hydrochloric acid to maintain a high acidity level. In general, 2-4M hydrochloric acid solutions seem satisfactory in allowing complete precipitation of zirconium by glycolic acid derivatives while at the same time assuring the selectivity of the method by minimising the precipitation of other cations. The need to use a lower acidity in the case of NMA is a distinct disadvantage.

In 4-6M hydrochloric acid, zirconium forms precipitates of the theoretical composition with MA; at a lower acidity, basic salts may be formed. The latter, is, however, of no consequence because the precipitate is finally ignited to zirconium dioxide.

Hafnium, of coursc, interferes quantitatively in all prccipitation methods for zirconium and, if present, will be measured along with it. The general selectivity of the method is indicated by the successful determination of small amounts of zirconium in complex samples. ${ }^{3}$

\section{Recommended procedures}

The following procedures are recommended for the determination of zirconium at the milligram level, using the precipitants indicated:

Mandelic acid (for $1 \mathrm{mg}$ or more of zirconium in 3-6M HCl): Heat the 10-ml sample solution to $50-60^{\circ}$ in a $50-\mathrm{ml}$ beaker, then add $10 \mathrm{ml}$ of $10 \%$ MA solution dropwise with constant stirring. Digest for $20 \mathrm{~min}$ at $80-85^{\circ}$. Filter and wash with a warm solution $(2 \mathrm{ml}$ of $\mathrm{HCl}+5 \mathrm{~g}$ of MA per $100 \mathrm{ml}$ ). Char paper and precipitate in a platinum crucible; ignite to $\mathrm{ZrO}_{2}$ at $900-1000^{\circ}$.

p-Bromomandelic acid (for 0.1 mg or more of zirconium in 1-4M HCl): Heat the 10-ml sample solution to $50-60^{\circ}$, then add dropwise $10 \mathrm{ml}$ of $1.5 \%$ BMA with constant stirring. Digest for 15 min at $80-85^{\circ}$. Filter, wash with $15-25 \mathrm{ml}$ of hot water; char and ignite in platinum crucible.

$\mathrm{m}-$ Nitromandelic acid (for $0.1 \mathrm{mg}$ or more of zirconium at $\mathrm{pH} \mathrm{1.3):} \mathrm{Heat} \mathrm{the} \mathrm{10-ml} \mathrm{sample}$ solution to $50-60^{\circ}$, then add dropwise $10 \mathrm{ml}$ of $15 \%$ NMA solution with constant stirring. Digest for $10-15 \mathrm{~min}$ at $60-70^{\circ}$. Filter, wash with $10 \mathrm{ml}$ of $5 \%$ warm NMA solution; char and ignite in platinum crucible.

Acknowledgement-One of the authors (MR) wishes to thank the International Atomic Energy Agency for a fellowship, which enabled this work to be carried out.

Department of Chemistry

The University of Michigan

Ann Arbor, Michigan, U.S.A.
MOHAMMED RAFiQ*

Charles L. Rulfs

PhILIP J. ELVING

Summary - The limiting factors have becn investigated for prccipitation of zirconium at the milligram level by mandelic acid, $p$-bromomandelic acid and $m$-nitromandelic acid; the latter has only been briefly studied previously. Optimum conditions have been determined for quantitatively precipitating zirconium at $0 \cdot 1-$ and $1-\mathrm{mg}$ levels.

* Present address: University of Kabul, Kabul, Afghanistan. 
Zusammenfassung-Die Empfindlichkeitsgrenzen für die Fällung von Zirkonium mit Mandelsäure, p-Brom- und $\mathrm{m}$-Nitromandelsäure im Milligrammbereich wurden ermittelt; die Fällung mit m-Nitromandelsäure war vorher nur oberflächlich untersucht. Die optimalen Bedingungen für die quantitative Fällung von Zirkonium in Bereich von 0,1-1 mg wurden ermittelt.

Résumé-Voici une étude des facteurs limites de la précipitation du zirconium en quantités de l'ordre du milligramme par les acides mandélique, $\mathrm{p}$-bromomandélique et $\mathrm{m}$-nitromandélique, ce dernier n'ayantété précédemment étudiés que d'une manière superficielle. Les conditions optima de la précipitation quantitative du zirconium pour des teneurs variant de 0,I à I mg. sont déterminées.

\title{
REFERENCES
}

${ }^{1}$ R. E. Oesper and J. J. Klingenberg, Analyt. Chem., 1949, 21, 1509.

${ }^{2}$ R. B. Hahn, in I. M. Kolthoff and P. J. Elving, Treatise on Analytical Chemistry. Interscience Publishers, New York, 1961, Part II, Vol. 5, pp. 61-138.

${ }^{3}$ M. Rafiq, C. L. Rulfs and P. J. Elving, Talanta, 1963, 10, in press

\section{Precipitation from homogeneous solution with $N$-benzoylphenylhydroxylamine acetate}

\author{
(Received 9 November 1962. Accepted 14 January 1963)
}

IN 1950, $N$-benzoylphenylhydroxylamine (BPHA) was introduced by Shome $^{1}$ as a precipitant for aluminium ${ }^{\mathrm{III}}$, copper ${ }^{\mathrm{II}}$, iron ${ }^{\mathrm{III}}$ and titanium ${ }^{\mathrm{IV}}$. Since that time it has also been used to precipitate beryllium ${ }^{\mathrm{II}},{ }^{2}$ cobalt $^{\mathrm{II}},{ }^{3}$ nickel ${ }^{\mathrm{II}},{ }^{8}$ molybdenum ${ }^{\mathrm{VI}},{ }^{4}$ niobium $^{\mathrm{V}}{ }^{5,6}$ tantalum $^{\mathrm{II}},{ }^{5,6}$ tin $^{\mathrm{IV}},{ }^{7}$ zirconium ${ }^{\mathrm{IV}}, 8,8$ scandium $^{\text {III, }}{ }^{10}$ thorium ${ }^{\text {IV }}$ and cerium ${ }^{\text {III }}$.11

BPHA has three important characteristics which make it preferable to cupferron which it resembles. It is a stable compound, more effective separations can be achieved and it forms stoichiometric compounds with most ions, so enabling the complex to be weighed directly instead of necessitating ignition to the oxide.

The present investigation was undertaken to explore the usefulness of $N$-benzoylphenylhydroxylamine acetate (BPHAA) as a reagent for the in situ generation of BPHA. Copper was arbitrarily chosen as a model ion with which to test the new reagent.

\section{Reagents}

\section{EXPERIMENTAL}

Copper solution: Copper metal $(99.9 \%)$ was dissolved in nitric-hydrochloric acid. The concentration of copper in the solution was determined by electrolysis, by precipitation with BPHA and by iodometric titration. U.S.A.

BPHA: Eastman Organic Chemicals, Distillation Products Industries, Rochester 3, New York,

BPHAA: This is a new PFHS compound manufactured by Burdick and Jackson Laboratories, Muskegon, Michigan, U.S.A.

All other chemicals used were reagent grade.

\section{RESULTS AND DISCUSSION}

As a result of preliminary investigations, the following procedure was devised:

Solutions containing 1 to $25 \mathrm{mg}$ of copper in a 400-ml volume were buffered at $\mathrm{pH} 4.5$ with $0.1 \mathrm{M}$ acetic acid- $0.1 M$ sodium acetate buffer. The solutions were heated nearly to boiling and $19 \mathrm{ml}$ of an ethanolic solution, containing twice the theoretical amount of BPHAA required to precipitate the copper present, were added with stirring. The beakers were then immersed in a constant temperature bath $\left(65^{\circ}\right)$. After $24 \mathrm{hr}$, one tenth of the theoretical amount of BPHA* in $1 \mathrm{ml}$ of ethanol was added

* This is a precautionary measure to make certain of the removal of final traces of copper, especially if there is doubt as to the full maintenance of the proper temperature throughout the period of precipitation (cf. Gordon, Salutsky and Willard ${ }^{12}$ ). 